Christian Freigang

\title{
UNIVERSITY LANDSCAPE ARCHITECTURE: GÖTTINGEN IN THE AGE OF ENLIGHTENMENT
}

Göttingen is hardly a place where architectural history is written. The town never housed a princely residence nor was it the home to patrician worship and pride. Until the $18^{\text {th }}$ century the town was a small, semi-rural, semi-urban town, where the cloth trade flourished and peasants grazed their cattle in the nearby suburbs. In fact, the most important impact on the town's urban development was the establishment of the university in 1734, by George Augustus, Elector of Brunswick-Lüneburg, also known as George II, King of Great Britain and Ireland. ${ }^{1}$ However, the newly created departments were not housed in impressive buildings, instead, existing structures or relatively modest buildings were mostly used. And with some very striking exceptions, it was not until the $19^{\text {th }}$ century that a typology of academic buildings evolved. Nevertheless, if one views university landscape as a social topography, the new function of the town rapidly and profoundly altered the urban qualities of Göttingen. New administrative structures, the specific needs of the faculties, as well as changes in the residential culture and social practices of the

DOI: https://doi.org/10.12697/BJAH.2018.15.08

1 These changes are best described in various studies in: Göttingen. Geschichte einer Universitätsstadt, Bd. 2. Vom Dreissigjährigen Krieg bis zum Anschluss an Preussen - Der Wiederaufstieg als Universitätsstadt (1648-1866), ed. by Ernst Böhme, Rudolf Vierhaus (Göttingen: Vandenhoeck \& Ruprecht, 2002), passim, here also my general study 'Architektur und Städtebau von der Mitte des 17. Jahrhunderts bis 1866 ', $765-812$. 
academic population modified, à la longue, the architectural and urban form of the town. In fact, the term 'university landscape' can rightly be used in this context because the modifications within the social space had a considerable impact on the urban space. ${ }^{2}$ Teaching and studying can occur independently of landscape, but riding, fencing, and promenading required structures related to the landscape.

\section{GÖTTINGEN BEFORE THE UNIVERSITY}

Dependent on the Electorate of Hanover in the $17^{\text {th }}$ century, the town's economic wealth was derived mostly from textile and leather production, and it housed a garrison. Surrounded by almost circular double fortifications, the urban structure was largely untouched since the Late Middle Ages. The centre was defined by the town hall and the market, dominated by the major parish church of St John. The north-south axis, today Weender Strasse, passed through the town. The remaining space was subdivided into two parishes, St James and St Alban. In many places, its inner periphery was characterised by sparsely populated arable lands and pastures. In contrast to this rural periphery, a series of relatively high, three-storied and side-gabled timbered houses had been built since the $16^{\text {th }}$ century, especially along the main axis, parallel to the Jüdenstrasse. These relatively modest, but very flexible and functional, houses would be the most important dwelling type until the $20^{\text {th }}$ century. But the Thirty Years War had largely devastated the town and it had hardly recovered

2 Johann Stephan Pütter, Friedrich Saalfeld, Georg Heinrich Oesterley, Versuch einer akademischen Gelehrten-Geschichte von der Georg-August-Universität zu Göttingen, Bd. 1-4 (Göttingen: Vandenhoeck \& Ruprecht, 1765-1838), passim; numerous contribution in Göttinger Monatsblätter; Sabine Kastner, 'Bauen und Wohnen in der ersten Hälfte des 18. Jahrhunderts', Göttingen im 18. Jahrhundert. Eine Stadt verändert ihr Gesicht (Göttingen: Städtisches Museum, 1987), 215-246; Jens-Uwe Brinkmann, “Der gantzen Stadt zur Zierde und Annehmlichkeit." Die öffentliche Bautätigkeit', Göttingen im 18. Jahrhundert. Eine Stadt verändert ihr Gesicht (Göttingen: Städtisches Museum, 1987), 255-324; Sabine Kastner, 'Bürgerliches Wohnen und Bauen in Göttingen', Göttingen 1690-1755, ed. by Hermann Wellenreuther. Studien zur Sozialgeschichte einer Stadt (Göttingen: Vandenhoeck \& Ruprecht, 1988), 175-251; Alfred Oberdieck, Göttinger Universitätsbauten. 250 Jahre Baugeschichte der Georg-August-Universität (Göttingen: Verlag Göttinger Tageblatt, 1989); Bärbel Schwager, Das Göttinger Auditoriengebäude von 1862/65. Ein Beitrag zur Universitätsarchitektur im 19. Jahrhundert und zur Hannoverschen Variante des Rundbogenstils. PhD Dissertation (Göttingen: Georg-August-Universität zu Göttingen, 1994); Göttingen: das Bild der Stadt in historischen Ansichten; eine Auswahl aus der Graphischen Sammlung des Städtischen Museums, ed. by Jens-Uwe Brinkmann (Göttingen: Städtisches Museum, 1996); Rolf Wilhelm Brednich, Denkmale der Freundschaft. Die Göttinger Stammbuchkupfer. Quellen der Kulturgeschichte (Friedland: Bremer, 1997); Helga-Maria Kühn, Hundert Häuser. Hundert Tafeln. Ein Führer zu Göttinger Baudenkmälern (Göttingen: Göttinger Tageblatt, 1998). 
from this decline by the beginning of the $18^{\text {th }}$ century. Then, as the result of several rebuilding programmes, along with the establishment of the university, an era of economic and architectural wellbeing was restarted. In fact, the town's relatively good infrastructure, in economic as well as in spiritual terms, is supposed to have been the decisive factor in choosing Göttingen as the site for the princely university of Hanover. Nevertheless, the new sense of wellbeing left the embankment and the social structure of the town largely unchanged. Namely, the humid north-western quarter with its pitiful houses was still being used for agriculture, and it was in this impoverished part of the town that the new university was built.

\section{URBANISTIC INTERVENTIONS IN THE $18^{\mathrm{TH}}$ CENTURY}

The establishment of the university was immediately followed by a profound change in the town's status. The prospering centre for textile mills and leather tanneries, commerce, and military defence would now be dominated by the university's administrative and educational needs. And one of the many consequences of these building activities was to furnish the town with infrastructural resources. Some general remarks can summarise this urban reconstruction. Firstly, a certain liberty was accorded to unconventional solutions, due to the absence of architectural traditions. A newly founded Policy Commission coordinated the interests of the town, the university, and the government. Secondly, because the new university focused on the natural sciences from the beginning, innovative architectural solutions were needed. But significantly, and this is the third point, improvements in the organisation of green spaces were designed. Trees were planted in places, but in particular, an existing path in the poor northwest quarter was enlarged and edged with two rows of trees, separating the two sidewalks and a bridle path in the middle. This new axis would soon become the main promenade, later the Goethe-Allee. The prestigious promenades were clearly inspired by aristocratic models, namely in Hanover. In 1726, the princely garden at Herrenhaus had been linked to the town by a large lime tree avenue called the Neue Allee, and promenades leading to the woods of Eilenriede nearby were also the latest fashion at this time. Very quickly, the entire quarter of Göttingen developed into a 
noble settlement and the main residential area for the newly arrived professors. They were allowed to have large gardens and, in the last third of the $18^{\text {th }}$ century, after the Seven Years War, the dismantling of the fortifications began in order to beautify the town and create more green space for promenading. In fact, this successfully responded to the demands of the aristocratic professors and the students, who were different from the ordinary citizens. And until the beginning of the $19^{\text {th }}$ century, the town's citizenry was subject to different legislation and justice systems than the university faculty and students, causing mistrust and antipathy among the ordinary population.

Until the first third of the $19^{\text {th }}$ century, numerous streets, including in the western and southern parts of the town were extended, paved, and partially illuminated. Those traffic improvements were accompanied by new public buildings, such as a brewery, weighing house, post office and orphanage. The most important measure in this context was the construction of a new and spacious building for the respected public school in the eastern quarter. This was a direct consequence of the installation of the university in a vast complex in the ancient Black Friars monastery close to the centre of Göttingen. Thus, right from the start, the university superposed the ancient centre and caused a general expansion and regulation of the town. And within a couple of decades, it also induced an adaption to aristocratic lifestyles.

The new university manifested itself with direct architectural interventions. The reuse of the Black Friars monastery not only entailed a complete renovation of the interior, but also a totally new construction, built on the foundations of the cloisters. This work was executed by Joseph Schädeler, between 1733 and 1737, simultaneously with the founding of the university. Schädeler's plan was pragmatic as well as intelligent. The four, now two-storied, wings of the ancient cloisters were harmoniously repartitioned into four faculties. Each of them was accessible by a large, but sober portal, installed in the centre of each wing. Thus, the building was open to the town on three sides. Nevertheless, Schädeler accentuated the north side with double stairs, with the door opening onto the eastern end of the Allee. The building faced the administration building of the university building and the academic council's building on the opposite side. Significantly, the area between the Konzilienhaus and the main entrance of the main building were sealed off by an iron fence with a gate, and thus 
closed off the urban space. Therefore, the university occupied a vast area, extending from the noble Allee to the ancient monastery and, in a way, the topography formed a palace-like ensemble within the town. Near the Allee, Schädeler designed an academic fencing hall, indispensable for the aristocratically-inclined faculty members, who built their houses nearby - mostly large structures, in a sober style and without formal spaces. The frontier between the 'academy and the townhouses' (to quote a contemporary) was reinforced by a large ephemeral triumphal arch, that was erected at this spot in 1748 , on the occasion of King George II's visit to the university. But this was not all. On the western side of the main axis near the north gate of the town, Schädeler built the academic riding hall, which included a vast hippodrome and stable. Thus, within a few years the university had completely transformed the urban space of the town, by occupying a quarter of it. The elements of this composition were clearly derived from an aristocratic residential typology: the main building can be seen as a four-winged castle, forming the point de vue of the Allee, surrounded by promenades and specific sporting facilities. Nevertheless, the execution of all these architectural elements followed a very pragmatic logic and avoided any opulent decoration. This corresponded perfectly to the self-image of the first generations of professors, who were described as sober and pragmatic, more dedicated to science than aristocratic rituals. For instance, in the case of the Hainbund literary circle, strolling often turned into pre-romantic wanderings in the surrounding hills where they could enthuse about nature and Rousseau.

However, this did not exclude further interventions whereby aristocratic dominance, scientific interest and religious demands contributed to a profound remodelling of the town. The best example of this is the botanical garden (1739), designed by Albrecht von Haller, a medical doctor, natural scientist and poet who was appointed in 1736. The garden was installed in the north-eastern part of Göttingen and strictly followed scientific principles. Nearby, he constructed his own dwelling, as well as two completely innovative edifices. The anatomical theatre, with its amphitheatre and bright lights, relied on new methods of medical teaching from the Netherlands. The same can be said of the Reformation church, built in 1738 by Haller in order to obey his faith. The church is one of the major examples of Reformation-era ecclesiastical building, influenced by 
Swiss and Netherlandish models. Even if the exteriors of the two buildings do not provide any remarkable decorations, it is the clear and sober outline of the facades and innovative inner organisation of the buildings that contributed considerably to the town's image as a place of sound Enlightenment culture.

This urban recovery immediately precipitated other architectonical undertakings. In 1739 the entrepreneur Johann Heinrich Grätzel, who owned some of the professors' houses, built a large, palace-like building at the beginning of the Allee. This was a typical investment project and included ambitious, but nonetheless somehow awkward, decorations (which have been lost). Architectural ambitions and discourses were new to Göttingen, but the demand for them was answered by the university. Johann Friedrich Penther, an architectural theorist, was appointed in 1736 to lecture on the art of building. His academic papers were published in two important and very well illustrated books, the Collegium Architectonicum and the Anleitung zur Bürgerlichen Baukunst, both of which combined the essentials of architectural composition with very detailed descriptions of housebuilding practices. And Penther was also completely aware of the architectural scene of his day, as can be seen in the presentation of some of his innovative contemporary projects.

\section{BUILDING ACTIVITY IN LAST THIRD OF THE $18^{\mathrm{TH}}$ CENTURY}

By the end of the $18^{\text {th }}$ century, Göttingen University was unquestionable at the peak of its reputation. And as the need for a more differentiated alma mater developed, subsequent architectural projects slowly but steadily invaded all quarters of the town. In some cases, these included specialised and well-decorated houses of science. The first was an autonomous university library, in 1765. It is noteworthy that, in Göttingen, scientific writings were not stored in the private houses of the professors or in the faculty rooms. A series of important donations, and especially the very concise and well-financed acquisition policy of the antiquarian Christian Gottlieb Heyne, who in many regards was the spiritus rector of the university, made the Göttingen collection one of the earliest and the most important university libraries of its time. The collection had to be housed in an autonomous building, and the discussion turned 
rapidly to the question of whether, and how, two former mendicant churches could be rehabilitated for this purpose. However, Johann Dietrich Heumann, the son of the Hanover court architect Daniel Georg Heumann, proposed that a large library building should be erected at the end of the Allee. The multi-storied palace-like building was to be dominated by a large central reading hall, crowned by a cupola. It recalled the large Vienna Court Library, designed by Johann Bernhard Fischer von Erlach, and would have given this quarter a truly princely appearance. Finally, an extension to the eastern wing of the Black Friars cloisters was designed by Georg Heinrich Borheck, the new academic architect. Even if the architecture was sober and functional, and remained a part of the academic building complex, it should to be pointed out, that the library now provided a very large area to store and study books and discuss their contents.

Borheck designed many buildings in and around Göttingen, but his major work is again a highly original academic building. The maternity hospital, the first of its kind in Germany, was erected between 1785 and 1787 in the southern part of the town. The very meticulously planned concept - the most important specialists were asked for their advice - had to provide good hygienic conditions, namely good aeration. For this, the site near the southern gate of the town, in the middle of the gardens, was ideal. However, the architect not only needed to create a picturesque piece of architecture but had to adhere to a hygienic agenda. Borheck planned a large building on a h-shape floor plan and Late Baroque decoration and surrounded by a long, extended garden. On the sides, large three-bay windows on each storey open up the wall, and inside, there is a circular opening in the centre of the building. This arrangement clearly improved lighting and aeration, while also adding grace to its well-oriented structural exterior, resulting in a monumental palace of science that has dominated the southern gate of the town ever since.

By this time, Göttingen had been completely transformed into a university landscape, and its urban space extended from the north to the south. In terms of social space, it was dominated by the somewhat arrogant and elitist culture of the students. In fact, many of the German intellectuals of this epoch were educated here: the Schelling brothers, Johann Heinrich Wackenroder, Achim von Arnim, Clemens Brentano, as well as the Humboldt brothers, Freiherr von Stein, Freiherr von Hardenberg, and others. Of course, this conjuncture produced 
considerably building activity: dwellings and merchant houses etc. needed to be built, enlarged and embellished, especially on the main axis. But the dominant urbanistic factor remained the university and its landscape: the Allee, the riding area, the botanic garden, the maternity hospital, and in a way, the rampart promenades where students spent their leisure time - Heinrich Heine's melancholic love poem 'Auf den Wällen Salamankas' is in fact based on his student life in Göttingen.

The importance of an adequate building typology and landscape environment can be underlined by the career of Borheck himself, in which some major changes can be observed regarding the issue of an adequate architectural representation of the university. Borheck's projects were intelligent in their inner organisation, but in terms of style, they remained mostly indebted to a simple and functional Late Baroque idiom and were hardly debated in public. However, Borheck was apparently fully aware of the architectural discourse of the day, for he compared - somehow illogically - his maternity hospital to Florentine Renaissance palaces as well as buildings by the contemporary and very innovative architect Claude-Nicholas Ledoux. But this was just magnanimous lip service, and not confirmed by the building itself. Nevertheless, the fact that Borheck felt obliged to repeat such a pretention reveals that the ideas of style and taste were about to become increasingly important around 1800. Criteria such as actuality and convenience had to be respected, and this new awareness was not only obvious in academic circles but among the public as well. This resulted in a new appreciation of Greekinfluenced neoclassicism on the one hand, and the neo-medieval idioms on the other. At the end of his long life, Borheck despaired of the victory of these new styles as practiced by his followers. From then on, academic architecture not only expressed its meanings in terms of its site within the urban topography, but also by promoting significant styles.

\section{THE TURN TOWARDS NEOCLASSICISM}

The success of Göttingen University and a new semantic of style constituted two important factors in providing the town's outskirts with a partly university landscape. In fact, academic buildings were some of the most ambitious projects when the building activity began 
to spill across the town's old borders around 1800. Two ambitious projects should be mentioned here: the observatory and the new anatomical theatre. In 1802, the university administration charged Borheck with designing the observatory, since astronomy had become an increasingly respected and prestigious discipline. Borheck planned it as a three-winged palace-like building crowned by a dome for the telescope. Renowned experts in astronomy and architecture were consulted for this technically quite difficult task. Borheck finally used the observatory of Gotha as model for his richly decorated project, which, in Borheck's words, was supposed to demonstrate 'a firm and noble character' and be able to 'stimulate imagination and induce issues to be reflected upon'. He even wrote a detailed treatise on the construction of observatories. The construction was completed up to the terrace level but had to be stopped after the French invasion of the town in 1805, whereupon Borheck withdrew to Cassel. A new attempt wasn't undertaken until 1810, when King Jérôme, the new Napoleonic ruler of the territory, demanded the realisation of the project. It was executed by the Departementsoberbaurat August Leopold Crelle, based on the expertise provided by Generalbauinspektor Jussow in Cassel. Led by the new university architect Justus Heinrich Müller, the building was finally completed in 1816, and was located at the southern outskirts of the town, in the middle of a small garden. Despite the fact that the new project took over the existing foundations and generally followed Borheck's plans, it was clearly modified stylistically. The pilasters were abandoned, and the columns replaced with true Greek Doric. Borheck, who visited the building in 1812 , was scandalised by these alterations and harshly criticised them purely out of artistic jealousy. The observatory affair demonstrates what an ambitious project the building was in technical as well as in stylistic terms. To understand its true importance, one must take into consideration the fact that the university was in a veritable tug-of-war with the planned university of Brunswick, to secure the appointment of the famous mathematician Carl Friedrich Gauss. Göttingen finally won this battle, and Gauss became one of the most prestigious figures within the university. But the observatory adopted this modern stylistic idiom not only because they wished to attract Gauss. When King Jérôme, the French king of the newly created Kingdom of Westphalia, was installed in Cassel, the entire region became a centre of Enlightenment culture. A building academy, 
directed by Johann Heinrich Jussow, which adhered to the Parisian classicist idiom, was founded in Cassel. And in fact, it was Jussow who examined Crelle's and Müller's project, and Crelle himself who occupied the post of an Oberbaurat in Westphalia. And Müller, the new academic architect, had also studied architecture under Jussow. Thus, the observatory affair marks an important turning point by demonstrating very clearly how the circumstances and horizons of knowledge were changing, due to the new administrative structures on the one hand and a new awareness of style on the other.

Another large project confirms the impact of the new neoclassicism. One of the last works by Justus Heinrich Müller was the anatomical theatre, which was being planned since 1819, but not executed until 1828-1829, and destroyed at the end of World War II. The cubic building had a columned portico and dome, with a wide exedra at the rear to house the well-lit auditorium. The building on the western outskirts of the town not only adhered to a noble stylistic idiom but formed an important point of view for the Alleestrasse. The street itself received a new and noble planting of maples and was linked to the anatomical theatre by an English-style green. In 1821, Müller built a triumphal arch north of the Allee on the site of the academic hippodrome. Some twenty years later, the university hospital was built at the southwest end of the Alleestrasse with a beautiful park opposite it. Thereafter, the university area between the anatomical theatre and the college building in the centre was crossed by a renewed and noble promenade that would soon serve as the main axis into the town after the train station was built next to the anatomical theatre in 1854 .

However, the building activity in the centre of Göttingen did not cease at that time. A few decades after its enlargement, the library had to be expanded once more. In 1801 Borheck presented two alternative projects for a new building on the site of the Dominican church. However, for financial reasons, these ambitious plans were never realised. Instead, it was decided that the church itself should be used as a book depository, reading room, and auditorium. None other than Friedrich Weinbrenner, the famous classist architect, designed the new project. Once more, the responsible architect Borheck was ousted, but he was at least charged with executing the project. Due to the invasion by the French army, the project was delayed, and in the end, it was up to the new architect Müller to complete the work 
between 1808 and 1812. A floor subdivided the church's interior into two spaces. The ground floor was used as an auditorium and the very high and bright upper story was redesigned into a reading area and the book depository. Weinbrenner, later known for his slightly earlier neoclassicist works in Karlsruhe, showed himself to be very sensitive to the stylistic unity of the medieval building, which dated from the early $14^{\text {th }}$ century. Thus, the furnishings required for storing the books imitated medieval tracery, and the western facade was embellished with adopted medieval forms, such as a large tracery window. All these forms could be found in the illustrated books on medieval monuments, available in the library itself. Thus, the renovation was seen as one of the earliest Gothic Revival ensembles in Germany and confirms once more the awareness of the significance of architectural styles at this moment. Neoclassicism and Gothic Revival are part of a universalistic understanding of science, wherein the history of architecture played a new role.

One last building needs to be discussed, for it forms, as well as its association with the climax and dusk of the architectural landscape of Göttingen. The new Assembly Hall (Aula), containing an auditorium maximum and meeting room for the Academy of Science, was built on the occasion of the university's centenary. The new architecture completed the centre of civic life created by the public authorities in the eastern part of Göttingen, in the vicinity of the New Market. A grammar school had been built here, along with a concert hall and a small theatre. The new assembly hall building made use of the outstanding site to demonstrate the university's reputation, especially in the light of the competing institutions in Halle and Leipzig. Between 1834 and 1837, Otto Praël, the new academic architect, designed a significant building in the late neoclassicist style, clearly referring to Schinkel's idiom In the centre of the square, the famous sculptor Ernst von Bandel erected a statue in honour of Wilhelm IV, who had donated the new auditorium. The entire ensemble clearly forms the climax of the architectural representation of the university. However, even more importantly it shows the new dominance of the humanities as the key sciences in Göttingen. The archaeologist Karl Ottfried Müller designed a complex iconographic program, based on Greek and Roman antiquity as the origins of arts and science. The T-shaped building also contained the rooms of the Academy of Sciences of Göttingen, painted in a neo-Pompeian style 
that was based on Greek vase painting and focused on the importance of historiography. However, the main room - the great auditorium on the first floor of the rear wing - was based on the forms of the Parthenon in Athens. Thus, the walk upstairs could be compared to the ascent to the Acropolis, which was regarded as the architectural climax of Greek civilization. The main facade not only dominates the structure, but with its gabled pilaster motif, alludes to the portico of a Greek temple and the large auditorium behind the facade. Ottfried Müller complemented this with his own house, a veritable urban villa in the Greek style, constructed between 1835 and 1836 by Christian Friedrich Rohns, a local architect and construction entrepreneur.

However, things changed rapidly and very significantly immediately after the Assembly Hall was completed, when the constitutional scandals of the day terminated the Age of Enlightenment in Göttingen. The king's refusal to accept the Constitution caused seven professors, called the Göttinger Sieben that included the Grimm brothers, to protest. They were immediately dismissed and banned. The consequences were serious, for Göttingen University not only lost seven experts but its reputation as a model of enlightened higher education. The number of students decreased, and although some important university buildings had been started since mid-century, the dominant impact of academic architecture on the town came to an end. And when the University town was finally integrated into the Prussian state in 1866, new aspects of urban identity - military, industrial production, education etc. - began to compete with the former role of the university landscape.

In summary, it should first be pointed out that the rather conventional aristocratic culture of the first generations of professors was instrumental in determining the landscape elements related to the $18^{\text {th }}$ century history of Göttingen University. Indeed, the topography with a palace-like main building and the Allee reminds us in a way of princely residences. But these formal features were rapidly transformed to serve scientific ones. The botanic garden has nothing to do with Baroque gardens, the free spaces surrounding the maternity hospital were designed for hygienic purposes, and the observatory 
demanded a non-obstructed view. Nevertheless, those generous green spaces contributed to the integration of the university into the public urban space and to keep the new institution omnipresent. The architectural typology or decoration of the facades were not the main feature of a new and different display of power in an academic town like Göttingen. Instead, it was the occupation of the urban space by the university buildings, thereby forming a landscape that is both real and symbolic. Secondly, a development can be perceived. Since late $18^{\text {th }}$ century university architecture has increasingly become a kind of an architecture parlante, but interestingly, it is not seen as something special or strange in the urban context. Buildings like the maternity hospital or the observatory are pretending to be noble palaces or suburban villas in a positive sense. This assimilation into the urban context changes at the end of the first third of the $19^{\text {th }}$ century, when the great Assembly Hall was built in a recognisable university typology. Thirdly, when talking about university architecture or university landscape, one must take into account questions related to the corporate identity of the institution. In the case of Göttingen, the sobriety and pragmatism of the early architecture corresponds to the self-image of the faculty. This - in some sense - anti-courtly attitude can be understood as being enlightened, and thereby did not impose itself via architectural monumentality. Consequently, the questions of typology and representability, at least in regard to some periods, became obsolete.

Christian Freigang: University Landscape Architecture: Göttingen in the Age of EnLightenment

Keywords: University of Göttingen; university ensemble; ARCHITECTURE; BOtANICAL GARDEN; ENLIGHTENMENT; NEOClASSICISM; Georg Heinrich Borheck; Otto Praël; Justus Heinrich Müller; FriedRICH WEINBRENNER

Christian Freigang is a Professor in the History of Art and Architecture at the Freie Universität Berlin. In 1990, he obtained his 
PhD degree for a study on the cathedrals of Narbonne, Toulouse and Rodez. Between 1991 and 1999, he worked as a lecturer at Göttingen University, where he obtained his Habilitation (1999) with a study on Auguste Perret, the conservative Revolution, and the architectural debate in France, 1900-1930 (published in German 2002). In 2003, he was nominated Professor in the History of Art and Architecture at Frankfurt a. M. University. His latest book is a handbook in architectural history, from 1800 to the present. His research domains cover the history and theory of architecture, especially $12^{\text {th }}$ to $16^{\text {th }}$ and $19^{\text {th }}$ to $20^{\text {th }}$ century, in France and in Germany. Selected publications include: Imitare ecclesias nobiles. Die Kathedralen von Narbonne, Toulouse und Rodez und die nordfranzösische Rayonnantgotik im Languedoc (1992); Das Aula-Gebäude der Georg-August-Universität Göttingen (2006); Meisterwerke des Kirchenbaus (2009); Die Moderne. 1800 bis heute. Baukunst - Technik - Geschichte (WBG-Architekturgeschichte, vol. 3, ed. by Christian Freigang, 2015, re-edited 2018). 